JOTS, 2/2, 2018: 26-49

\title{
Kutadgu Bilig'te Geçen Türkistan ve Turan Terimleri Üzerine
}

\section{On the Terms of Turkistan and Turan in Qutadyu Bilig}

\author{
Gaybullah BABAYAR
}

The al-Beruni Institute for Oriental Studies at the Uzbek Academy of Sciences (Tashkent/Uzbekistan)

E-mail: gaybullah@mail.ru

The thinker of the Qarakhanids period, Yusuf Balasayuni (11th Century) in his well-known work Qutadyu Bilig have noted the followings: '(...) in the Region of Mashriq (East), in the districts of Turkestan according to the language of Buyra Khan, this book (...) the Iranians called it as 'the Turkic Shah-name', (...) the Turanians named it as: 'The Qutadyu Bilig'. These notes may prove the facts that the terms 'Turkestan' and 'Turan' are closely connected with the similar geographical regions during the period of the Qarakahanids. This paper highlights how these terms are linked with historical realities and the issues of the origin of their usage.

Key Words: Pre-Islamic Central Asia, Qutadyu Bilig, Turkistan, Turan, Qarakhanids, Eastern Turkistan. 


\section{J(৫)}

\section{Giriş}

Karahanlılar döneminin başta gelen edebî eserlerinden Kutadgu Bilig'in giriş kısmında kitabın yazarı Balasagunlu Yusuf (XI. yüzyıl), "Maşrık vilayetinde, Türkistan illerinde Boğra Han dilince bu kitap (...) İranhllar Şah-name-i Türki dediler, (...) Turanlllar Kutadgu Bilig diye söylemişler" kaydını düşmekte, daha sonraki satırlarında ise kendisinin şöyle bir şiirini sunmaktadır:

İranliglar Şehname ter muyar

Turanlıglar Qutadgu Bilig teb uqar

"Irranllar buna 'Şehname' derler, Turanllar 'Kutadgu Bilig' diye anarlar)" (Arat 1947: 48-49, 52-54; 1959: 1, 4).

Bu kayıtlar Karahanlılar döneminde Türkistan ve Turan kavramlarının Türklerle ilişkili eşanlamlı birer coğrafî adlar olduğunu kanıtlamaktadır. Peki, böyle bir kavram ne gibi tarihî gerçeklerle bağlantılıdır, kökeni hangi dönemlere ulaşmaktadır?

Bu sorularla ilişkili olarak akla gelen ilk cevap ise "Karahanlılar döneminde Orta Asya ve civarı Türklerin egemenliği altındaydı, buraların ahalisinin belirgin bir kısmını da çeşitli Türk boyları oluşturmaktaydı, o yüzden bölgeye Türkistan denmesi gayet doğaldır" olacaktır. Ancak, bu dönemde Turan tabirinin de Türkistan ile aynı anlamı ifade etmeye başlaması meselenin cevabının o kadar da basit olmadığını göstermektedir. Çünkü araştırmacılar arasında genel olan tanımlamaya göre, aslında, hem sosyal kültürel açıdan, hem de coğrafî yönden İran'ın karşıtı olan, ancak kökü İranî topluluklara dayanan Turan kavramı, Orta Asya'da Türk-İslam hanedanlarının egemenlik sağlamalarıyla, yani Karahanlıların X. yüzyılın sonlarına doğru Maveraünnehir'de hâkimiyeti Samanîlerin elinden almasıyla zamanla Türkistan tabiri ile aynı anlamı kazanmıştır.

Son yıllarda elde edilen bilgiler bu tarz açıklamaların tartışmalı olduğunu, her iki coğrafî terimin bütünleşmesinin daha erken tarihlere ulaştığını düşünmeye sevk etmektedir. İlkin, bu kavramın Karahanlılardan daha önce mevcut olduğu birçok kaynaklardan anlaşılmaktadır. Örneğin, döneminin önde gelen bilginlerinden Ebu Abdullah el-Harezmînin Mifatih Ulum 'Bilimler Anahtarı' (X. 


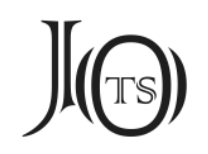

yüzy1l) ve Ebu Reyhan Birunî’nin (973-1048) Kanun-i Mesudî eserlerinde Horasan'da bulunan Merz-i Turan veya Mezduran mevziisi kaydedilerek, onun 'Türklerin sınırı' anlamına geldiği vurgulanmaktadır (Beruniy 1973: 466; Bahadirov 2009: 114). Diğer taraftan, bu kavramların kökü belki de bu tarihlerden daha önceki dönemlere, hatta İslam öncesine, Köktürk kağanlığı (552-744) dönemine kadar ulaştığını düşündüren farklı dillerdeki kaynak bilgilerinin bulunması konunun tekrar gözden geçirilmesini gerektirmektedir. Özellikle, Köktürklerle ilişkili olarak Türkistan tabirinin Soğd, Ermeni ve Pehlevî kaynaklarında görülmesi ve onun adı geçen Kağanlığı ifade eden etnik siyasî ve etnik coğrafî bir ad sıfatıyla, Turan tabirinin de daha çok siyasî anlam taşıyan bir tabir olarak Soğd dilli sikkelerde yer alması bu görüşü desteklemektedir. Bilhassa, miladî VI. yüzyılın sonları ile VII. yüzyılın ilk yarısında Semerkant'ta darp olunan bakır sikkelerde twrnyn $x w \beta w x^{\prime} \gamma$ 'n 'Turan hükümdarı Kağan' ve twrnyn $x w \beta w$ 'Turan hükümdarı' cümlelerinin görülmesi (Babayar 2017: 38-51) buna örnek teşkil eder (bk. Levha I, 1-5; Levha IV, Grup I. 2. Tip - Grup I. 4. tip).

\section{Konunun Araştırılması}

Gerçi XIX-XX. yüzyıllarda bilim dünyasında, özellikle Batı ve Rus edebiyatında Turan ve Türkistan terimlerinin kökeni ve onların tam olarak hangi topraklar için kullanıldığı konusu az çok incelenmiş olmasına rağmen, bu terimlerin ilkin hangi kaynaklarda görüldüğü, ilk kullanıldığı tarih, mekân vs meseleler yakın yıllara, yani XXI. yüzyılın başına kadar araştırma konusu olmamıştır. Nitekim, Türkoloji ve Türk tarihi araştırılması açısından önde gelen ülkelerden biri olan Türkiye'de bile bu konunun hemen hemen incelenmediği görülür. Oysa genel Türk tarihinin birçok sorunlarına çözüm getirmesi açısından bu terimlerin tüm boyutlarıyla incelenmesi gerekmekteydi.

Konunun daha kolay anlaşılması açısından bu kavramları iki alt başlıklar halinde kısa bir tarzda incelemeyi uygun görmekteyiz.

\section{I. İslam Öncesi Yazılı Kaynaklarında Türkistan Kavramı}

Orta Asya kadim tarihi ve Sogdoloji uzmanı Fransız VESSAİRE, kadim İran dilleri gözde uzmanı İngiliz SIMS-WILLIAMS gibi bilim adamlarının son yıllarda 


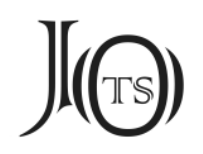

Soğd ve diğer İranî dillerde Türkistan teriminin İslam öncesi dönemlerde bile görülmesine dikkat etmeleriyle (Vaissière 2005: 169; Bo-Sims-Williams 2015: 262266) bu konuyu daha derin araştıran çalışmalar sürdürülmeye başlamıştır. Aslında bu konu daha önce, özellikle 1990'lı yıllarda Özbekistanlı Arap, Fars ve Türk dilli kaynak uzmanları araştırmıştır. ORINBAYEV, AHMEDOV, MANNANOV ve MAHMUDOV, arkeolog ASKAROV, Soğd dili uzmanı İSHAKOV, tarihçi ve Arap kaynakları bilimcisi KAMOLIDDIN ve s. bilim adamlarının, hem Arap, hem de İranî (Soğd, Pehlevi) ve Ermeni kaynaklarında görülen Türkistan ve Turan terimleri üzerine araştırma yapmaları veya diğer çalışmalarında atıfta bulunmaları konuya epey açıklık kavuşturmuştur (Urinboyev 1960: 84-85; Ahmedov 1992: 56; İshokov 1993: 1, 5; Askarov 1997: 67; Kamoleddin 2002: 61-68; Mannonov 1998: 6-8; Mahmudov 2003; Boboyarov 2004: 40-43; Babayarov 2008: 22-32). Yine de kaynak yetersizliği yüzünden Türkistan ve Turan terimleri üzerine onlar tarafından bildirilen açıklamalar epey eksik kalmıştır.

Bütün bunlara rağmen, konuyla bağlantılı biri diğerini tutmayan ve gerçek dışı açıklamalar yazılmaya devam etmektedir. Yani genel olarak bazı yayınlarda şu gibi bilimsel olmayan görüşlere denk gelinmektedir:

1. İlkin Arap istilası sırasında Sırderya'nın kuzeydoğusundaki Türk asıllı boyların yaşadıkları ülkeleri Araplar ve Farslar genel adla Türkistan adlandırmışlardir.

2. Amuderya-Sirderya arasındaki topraklara nispeten VI.-VIII. yüzyıllar için Türkistan terimini kullanmamak gerekir ki bu terim VIII.-IX. yüzyıllarda Sırderya'nın kuzeydoğusundaki ülkelere, esas olarak Sırderya nehrinin orta havzaları (Otrar/Yessi civarı) veya Yedisu'ya nispeten kullanılmıştır.

3. Amuderya-Sırderya arası, yani Maveraünnehir Türkistan'a dâhil olmamıştır, Türkistan derken Sırderya'nın orta ve aşağı havzaları, esas olarak bugünkü Türkistan şehri ve onun yakın çevresi anlaşılmıştır, sadece XIX. yüzyılın ikinci yarısında Ruslar, Orta Asya'yı el geçirince Türkistan adı onlar tarafından Sırderya-Amuderya arasına da kullanıla başlamıştır.

Aslında bu görüşlere kesin olarak yanıt verecek onlarca bilgiler Fars, Arap, Türk ve s. dilli orta çağ yazılı kaynaklarında bulunmaktadır. Ancak, biz burada 


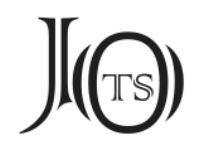

esas olarak Türkistan teriminin ilk kez görüldüğü erken orta çağlara, daha doğrusu İslam öncesi dönemlere ait kaynaklara müracaat etmeyi lüzum görmekteyiz.

Peki, adı geçen coğrafî terim tam olarak hangi tarihlerde görülmekte ve hangi topraklara nispeten kullanılmaktadır? Gerçi, Özbekistanlı tanınmış arkeolog RTVELADZE, VI.-VII. yüzyıllara ait Baktri (Doğu İran) dilli epigrafik buluntulardan birinde Türkistan tabirinin görüldüğünü bilim âlemine duyurmuşsa da (Kamoliddin 2010: 13) kaynak göstermediğinden dolayı bu görüşü şimdilik ihtiyatla karşılamak gerekmektedir.

Aslında, 639 yılına ait Soğd dilli bir belge ve VII. yüzyılın ilk yarısında yazılmış Ermeni kaynaklarında Türkistan tabirinin görülmesi VII. yüzyılın daha ilk yıllarında bu tabirin net olarak görülmeye başladığını kanıtlamaktadır. Nitekim Turfan (Doğu Türkistan)'dan bulunan 639 yılına ait Soğd dilli belgede "Çavyak boyuna mensup, Türkistan'da doğan cariye Opaçah" hakkında kayıt geçer. Uzun yıllardır Soğd kaynaklarını inceleyen Sogdolog İSHAKOV konuya ait "Namı ezel Türkistan" adlı makalesinde adı geçen belgede görülen bilgilerden yola çıkarak:

\footnotetext{
“Belgeden açıkça anlaşllıyor ki Türkistan coğrafî terimi ülkemizde (Orta Asya’ya) nispeten daha erken orta çağlarda kullanılmıştır, daha doğrusu bundan 1360-1400 yıllar önce Turan topraklarının genel adı Türkistan olarak adlandırılmaktaydı" diye vurgulamıştır (1993: 1, 5).
}

Yakın yıllarda ise Hotan (Doğu Türkistan)'da miladi VIII. yüzyıla ait birkaç Soğdça belgeler bulunmuş (bk. Levha V), onlardan birinin XIII. ve XV. satırla-

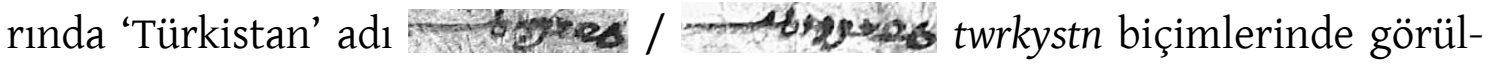
müştür (Bo-Sims-Williams 2015: 262-266). Bu belgeyi inceleyen SIMS-WILLIAMS, Türkistan tabirinin burada belirli bir bölge adı olarak geçtiğini vurgulamaktadır. Araştırmacıya göre, bu dönemde Türkistan adı kuzeydeki bozkırları, özellikle Sirderya nehrinden Moğolistan'a kadar uzanan bölgeyi ifade etmekte idi (Bo-Sims-Williams 2015: 268). 


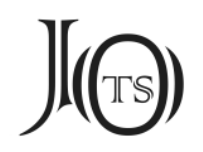

Bu belgeler hariç Türkistan adı üzerine daha teferruatlı bilgilerin görüldüğü ne gibi tarihî ve coğrafî eserler bulunmaktadır? Nitekim eserini miladi VII. yüzy1lın ortalarına doğru yazan Ermeni tarihçisi SEBEOS şu gibi önemli iki bilgiyi kaydetmiştir:

“Dihistan veya onun civarları Türkistan'dadır" (Frye 1946: 119).

“Kuşan Şahı (Eftalit/Ak-Hun hükmdarı) büyük Kağan'dan yardım istedi. Ve o, yardım için 30 bür (bir çeşit miktar) askeri ile yetişti. Onlar (Türkler) Türkistan'dan başlanan Vehrot (Amuderya) nehrinden geçtiler" (Ter-Mkrtiçyan 1979: 60-6).

Bu bilgiler tarihî Kuzeydoğu İran (şimdiki Türkmenistan'ın güney-batı kısmı) topraklarındaki Dihistan bölgesinin Türkistan'da bulunduğuna, Amuderya nehri kaynağının ise Türkistan'da oluştuğuna ima etmektedir. Bilindiği gibi, Amuderya'nın başlangıcı Vahş ve Penç nehirleri civarı (Tacikistan'ın güneyi ve Afganistan'ın kuzey topraklarına) denk gelir.

Diğer bir Ermeni tarihçisi, miladi VII. yüzyılda yaşayan Ananiya ŞiRAKATSİ kendisinin Aşharatsuyts Ülkeler Tasviri adlı eserinde "Soğdlular Aria (Horasan/Kuzeydoğu İran) ve Türkistan arasında yaşarlar" diye kayıt düşmüştür (Ter-Mkrtiçyan 1979: 63). Gerçi, bu bilgiden Türkistan'ın tam olarak hangi coğrafî bölgeye denk geldiğini belirlemek biraz zor olsa bile, bu dönemde Buhara ve Semerkant civarının 'Soğd bölgesi' olarak bilindiğinden şiRAKATSİ'nin betimlediği Türkistan'ın bu bölgeye yakın toprakları, bilhassa Amuderya-Sırderya nehirleri arası ve civarını içerdiği anlaşılmaktadır. Yani dönemin Ermeni ve diğer dillerdeki kaynakları böyle bir sonuca ulaşmamızı sağlamaktadır.

Elbette, Ermeni tarihçileri Türkistan'a dair bilgileri komşuları Farslardan almış olmalıdırlar. Zaten, Türkistan kelimesi ‘Türkler yaşayan mekân', 'Türklerin ülkesi' anlamındaki Farsça bir geleneğe dayanmaktaydı. Demek, Farslar miladi VI.-VII. yüzyıllarda da Türkistan terimini kullanmışlardır ki bu görüş erken orta çağlara ait Pehlevî (Orta Fars) dilli yazılı kaynaklarda da kendi tespitini bulmuştur (Markwart 1938: 123, n. 3).

Pehlevîce Bundahişn, Dünyanın Düzeni adındaki coğrafi eserde Türkistan'a dair şu gibi bilgileri kaydetmiştir: 


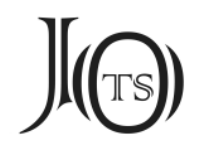

“Zarin dağı Türkistan'dadır; Saukavastan ülkesi Türkistan'dan Kinistan'a giden yolda, kuzey istikametinde bulunur; Kino dağı doğuda bulunur, o Türkistan sınırında olup, Aparsen dağı ile bitişiktir" (Pahlavi Texts 1987: 37, 41, 120).

Pehlevîce kaynaklardaki Türkistan'ın coğrafi konumunu tam olarak belirlemek için, hem adı geçen Saukavastan ve Kinistan ülkelerinin coğrafî mevkiini, hem de Zarin, Kino ve Aparsen dağlarının bugünlerdeki hangi dağlara denk geldiğini belirlemek gerekecektir.

İlkin, Zarin dağının hangi dağa denk geldiği meselesi üzerine duralım. Bundehişn'de Zarin dağı Horasan'daki dağlar sırasında kaydedilmesi onun yerini bu bölgeden aramayı gerektirmektedir. Nitekim Babür-name'de Afganistan'da geçen olaylardan bahsedilirken Kötel-i Zerin (Zerin geçidi) hakkında söz yürütülür (Baburname 1958: 194a, 226, 529). Araştırmacılar onu Kuzeybatı Afganistan'ın Kuhi Baba sıradağlarındaki Herirud nehrine yakın dağ geçidinin adı olarak açıklarlar. İlginç tarafı, bugünlerde bile bu mevki yakınındaki dağ, yani Herat ve Belh şehirleri arasındaki Kuhi Baba sıradağlarının bir kısmı Bendi Türkistan 'Türkistan s1radağı' olarak adlandırılır (Dames 1986: 221a; Boboyarov 2004: 41). Buna bakarak Bundehişn'de kaydedilen Zarin dağı ile Babür-name'deki Zerin dağ geçidi aynı olduğu söylenebilir. Burada, geçen yüzyıllarda olduğu gibi bugünlerde bile Kuhi Baba dağlarının kuzeyinden Amuderya nehrine kadar uzanan ve Bendi Türkistan sıradağını da kendi içine alan Kuzey Afganistan'daki vilayetlerin genel olarak Türkistan veya Güney Türkistan olarak adlandırılmasına dikkat etmek gerekmektedir. Bu ise, hem Ermeni kaynaklarındaki Türkistan'dan başlayan Vehrot 'Amuderya nehri', hem de Bundehişn'deki 'Zarin dağının bulunduğu Türkistan' bilgilerinin aynı topraklardan bahsettiğini ve coğrafî yönden burası Kuzey Afganistan topraklarını kapsadığı kanısını doğrular.

Pehlevî kaynaklarındaki, hem ‘Saukavastan' ve 'Kinistan' ülkeleri, hem de 'Kino' ve 'Apasen' dağlarının coğrafi mevkiine gelince, Kinistan ve Kino dağının Soğd bölgesi ve oradaki sıradağlara, Saukavastan ülkesinin ise bölgedeki Zerafşan nehri havzalarına denk geldiği anlaşılmaktadır. Büyük ihtimalle, Saukavastan Soğd'un merkezinde yer alan Zerafşan nehri havzasına değil, belki de bu nehrin kuzeyindeki geniş bozkır ve çöl araziye (Kızılkum çölüne) nispeten kullanıl- 


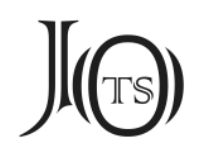

mıştır ki, bu yer adı Sak/Saka adının diğer bir şekli olabilir. Böylece, Pehlevî kaynaklarındaki Saukavastan'ın kaynağı eski Ahameniş dönemine ulaşan Sakastan/Sakistan'a ulaşır ve bu çöl hudut Saka boylarının konup göçtüŭü bölge olmalıdır. Horasan bölgesinin İslam öncesi dönemlerdeki diğer bir adı Apar olarak geçmesine bakılırsa, Pehlevîce metinlerdeki Aparsen dağının bu bölgedeki dağların genel adı olduğu anlaşılacaktır.

Demek, şimdiki Özbekistan ve Tacikistan arasında bulunan Hisar sıradağları1 Pehlevî dilli eserlerde Kino dağı, bu dağın bulunduğu coğrafî bölge ise Kinistan adı altında kaydedilmiştir. Kısacası, Bundehişn'deki mezkûr bilgilerden belli oldukça, Horasan'dan doğuya doğru Soğd istikametine giden yol ilkin Türkistan topraklarından, yani Dihistan'ın doğusu ve Amuderya nehrinin yukarı havzalarından geçmekteydi. 'Saukavastan ülkesi' ise bu yolun kuzeyinde bulunmaktaydl.

Pehlevî dilli yazarlar kendilerinin bulundukları İran toprakları istikametine dayanarak Dünya yönlerini belirttikleri, onların nezdinde Soğd ve diğer Orta Asya bölgeleri kuzeydoğu istikametinde bulunduğuna bakılırsa, Orta Fars kaynaklarındaki 'Türkistan'ın sınırları Soğd bölgesinden epey güney ve güneybatıdan başladığı anlaşılır. Eğer Soğd bölgesine komşu 'Saukavastan ülkesi, Türkistan'dan Kinistan (Soğd)'a giden yolda, kuzey istikametinde' ve Soğd'daki 'Kino dağı doğuda', o Türkistan sınırında ve Horasan'daki 'Aparsen dağı ile bitişik' olduğundan yola çıkılırsa, bu mesele yine de net aydınlık kazanacaktır. Nitekim Pehlevîce yazılı kaynaklardaki bu bilgileri aynı dilde yazılan miladî VI.-VII. yüzyıllara ait mühürlerde görülen ‘Turgistan’ adı da doğrulamaktadır (Gyselen 2002: 193; Kamoliddin 2010: 13).

Demek, İslam öncesi Ermeni ve Pehlevî kaynakalarındaki bu tür bilgilerden anlaşılacağı üzere, Orta Asya'nın güneybatı kısımları: bugünkü Güney Tacikistan, Güney Özbekistan, Güney Türkmenistan ve Kuzey Afganistan toprakları miladi

1 Hisar dağları - Özbekistan'daki merkezî ve güneydeki bir kaç vilayetlerin (Semerkant, Kaşkaderya ve Surhanderya) doğu topraklarında bulunan ve Tacikistan'ın kuzey batı topraklarından güneyine kadar uzanan, Özbekistan'la uzun bir sınır oluşturan sıradağların genel adıdır. 


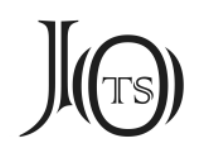

VI.-VIII. yüzyıllarda Türkistan'ın en uç güney hudutlarını oluşturmuş, bu terim buraların genel coğrafî adı olmuştur.

Türkistan coğrafî adının Orta Asya'nın birkaç bölgelerine denk gelmesi veya çeşitli kaynaklarda onun yeri farklı topraklarda gösterilmesi güya mesele teşkil eder. Ancak, diğer tarihî coğrafî ülkeler gibi Türkistan adının da çeşitli dönemlerde kâh daraldığı, kâh daha geniş alanı kapsadığı görülür. Elbette, bu durum siyasî değişimlerle sıkı sıkıya bağlı olmuştur. Gerçekten de, Arap coğrafyacıları Türkistan derken, daha çok Seyhun (Sırderya) nehrinin kuzeydoğu topraklarını kastetmişlerdir. Hatta o dönem kaynaklarında Türkistan ve Maveraünnehir ayrı ayrı ülkeler sıfatıyla kaydedildiği bilinmektedir.

Bilindiği gibi, Amuderya ve Sırderya nehirleri arası ve ona yakın topraklara nispeten 'Maveraünnehir' teriminin kullanılması mıntıkada Arap istilası (miladî VII.-VIII. yüzyıllar) sonucunda husule gelmiştir. Orta çağların Arap, Fars ve Türk dilli kaynaklarında ise Türkistan terimi daha çok Sırderya'nın orta ve aşağı havzalarına, bu nehrin kuzeydoğusundan doğuya doğru yer alan Tanrı dağlarının kuzey eteklerine, Yedisu, Fergana vadisi ve Doğu Türkistan'a nispeten kullanılmaya başlamışsa da, bazen Amuderya-Sırderya arası da onun muhtevasında yer aldığı bilinmektedir. Örneğin, Hafizi Ebru (XV. yüzyıl) kendisinin coğrafya eserindeki Maveraünnehir tavsifinde şu gibi bilgiler bulunmaktadır ki, bu kayıtlardan adı geçen iki nehir arasının da Türkistan dâhilinde sayıldığı anlaşılmaktadır:

\footnotetext{
"Söylentilere göre (...) Semerkant şehrini Şemer (adındaki) muteber bir emir inşa ettirmiş ve o Tubba' emirlerinden (Yemen ve Arabistan'ın İslam öncesi padişahları) olup, Türkistan’a yerleşmiştir. Bundan sonra o (şehir)i ‘Şemer-kend' demişler”(Büriyev 1997: 77).
}

Böylece, orta çağların çeşitli yazılı eserlerinde Türkistan tabirinin dar veya geniş anlamlarda kullanıldığına tanık oluyoruz. Bunu o dönemlerin siyasî ve coğrafî kavramlarının deformasyonu ile açıklamak mümkün. Örneğin, XVI. yüzyılda Türkistan adı geniş anlamda Kuzey Afganistan, Kuzeydoğu İran (Horasan) ve hatta Azerbaycan topraklarını da içine alan hudut için kullanıldığı durumlara denk gelinir. Özellikle, Kutb-name eserinde Şah İsmail Sefevî, 'Pir-i Türkistan' olarak kaydedilmesi bunun somut bir örneğidir (Dames 1986: 260a; Boboyarov 2004: 42). 


\section{J(৫)}

Yukarıda incelediğimiz bilgileri toparlarsak, miladî VII. yüzyıla ait Ermeni kaynaklarında anlaşılacağı üzere Ermeni müellifler, Hazar denizinin güneybatısı ve Amuderya nehrinin yukarı havzalarını Türkistan ülkesi veya bu ülkeye dâhil topraklar olarak biliyorlardı. Pehlevî (Orta Fars) kaynakları Kuzey Afganistan, Amuderya'nın yukarı havzası ve Horasan'dan Soğd'a, yani güneybatıdan kuzeydoğuya giden yolun Türkistan ülkesinden geçtiğini yazıyorlardı. Soğdça kaynaklarda ise (639), gerçi tam olarak anlaşılmıyorsa da, bu topraklardan kuzeydoğudaki ülkelere, büyük ihtimalle Sirderya nehrinin orta havzalarına ve Yedisu bölgesine 'Türkistan' denilmekteydi.

Aslında, Türkistan coğrafî terimi erken orta çağlarda bile İranlılar tarafından İran'ın kuzeydoğudan komşuları olan Türk ve onların egemenliği altındaki toplulukların yaşadığı bölge adı olarak 'Türk ülkesi', 'Türk devleti' anlamında kullanılmaya başlaması buralarda Köktürk Kağanlığının (552-744) hükümranlık yaptı̆̆ı dönemle bağlantılı olmalıdır. Aynı zamanda Türkistan terimini yakın komşuları olan İranlılardan öğrenen Ermeni tarihçi ve coğrafyacıları da kendi eserlerinde bu adı kullanmaya başlamış olmalıdırlar.

Buna benzer durum miladî VIII.-IX. yüzyıllara ait Tibet dilli kaynaklarda da görülmekte olup, Tibetçe Drugu-Yul 'Türkler ülkesi, Türkistan' tabiri bazen Batı Köktürk Kağanlığının merkezî toprakları, Yedisu (İli, Çu, Talas nehirleri havzaları), bazen ise Fergana veya Toharistan ve Kabulistan (Kabil vadisi) için kullanılmıştır (Uray 1979: 281 ).

Böylece, Türkistan coğrafî adının daha İslam öncesi dönemlerde de bugünlerin Orta Asya'sının büyük bir kısmı için etnosiyasî ve etnocoğrafî ad sıfatıyla kullanıldığına tanık oluyoruz.

Kısacası, adı geçen farkı dillerdeki kaynaklardan Türkistan'ın Köktürk Kağanlığını (ya da onun belirli bir kısım topraklarını) ifade eden etnik siyasî ve coğrafî terim olduğu anlaşılmaktadır. Demek, Köktürklere komşu (Fars, Ermeni, Tibet) veya ona tabi bulunan yerleşik topluluklar (Soğdlular ve s.), Kağanlık topraklarında çeşitli halklar yaşadıklarına bakmaksızın Orta Asya'yı 'Türkler ülkesi' anlamında Türkistan ve Drugu-Yul olarak adlandırmışlardır. 


\section{J(৫)}

\section{II. İslam Öncesi Yazılı Kaynaklarında Turan Kavramı}

Köktürk Kağanlığı döneminde Semerkant ve civarını (Zerefşan ve Kaşkaderya nehirleri havzalarındaki birçok hükümdarlıkları) kendi muhtevasına alan ve belirli bir konfederasyon düzeyinde olan Soğd bölgesinin merkezî hâkimiyeti makamında olan Semerkant, kendisinin çok asırlardır süre gelen sikke darbına sahipti. Semerkant sikkelerinde geleneksel olarak Aramî asıllı MLK' ve Soğdça $x w \beta$ 'hükümdar' unvanları görülmekle birlikte miladî VI. yüzyılın sonu ile VII. yüzyılın ilk yarısında darb olunan sikkelerde Turan adının görülmesi ilgi çekicidir (bk. Levha I, 1-5; Levha IV. Grup I, 2. tip - Grup I. 4. tip).

Özellikle, yakın yıllarda Semerkant'a ait ön yüzünde hafif çekik gözlü, yuvarlak yüzlü ve uzun saçlı hükümdar başı tasvirinin bulunduğu sikkelerde Soğd yazısılla $x w \beta$ twrnyn 'Turan hükümdarı' veya $x w \beta$ twrnyn $x$ ' $y^{\prime} n$ 'Turan hükümdarı Kağan' cümleleri bulunduğunun belirtilmesi (Babayarov-Kubatin 2010: 26-29. bk. Levha IV. Grup I, 2. tip - Grup I. 4. tip) bu konunun daha teferruatl incelenmesini gerektirmiştir. Hem, bu sikkelerin Eski Türklere özgü ikonografisi, hem de Köktürklere has kagan unvanın bulunması, onların barındırdığı Turan tabirinin bu açıdan değerlendirilmesini gerekli kılmaktadır.

İlkin, adı geçen sikkelerde akis olunan Turan sözcüğünün okunma tarzı ve telaffuzu konusuna kısaca değinelim. İtalik Soğd yazısıyla twrnyn biçiminde yazılan bu kelime Soğd dili kurallarınca tūrnīn tarzında yazıçevrimi yapılır. O, Turanyan < Turan+yan veya Turanen < Turan+en biçimlerinde iki kısımdan ibaret bir kelime olarak algılanabilir. Görünüşten bu kelimenin birinci kısmı, Turan 'yer adı' (toponim), \{+yan\} ve $\{+e n\}$ ise aitliği ifade eden Soğdça bir sonektir. Dolayısıyla, twrnyn kelimesindeki $\{+y n\}$ son eki mensupluğu bildiren ve sifat yapan ek olan Soğdça \{+yn'k\}, \{+yn'y\}, Mani-Soğdça \{+ynyy\} < *ainaka sonekinin kısalmış şeklidir (Livşits 1981: 439-440).

Bu sonek belirli bir yere, şahsa aitliği ifade ederek Soğdça yazılı eserler ve nümizmatik malzemelerde sıkça görülür. Örneğin, VII.-VIII. yüzyıllara ait Orta Asya'nın İslam öncesi birçok sikke çeşitlerinde ve Muğ dağı Soğd arşivi belgelerinde $c^{\prime} c^{\prime} n, c^{\prime} c n ' k w, c^{\prime} c y n k$ 'Çaç'in / Çaç'a ait' (Livşits 2008: 311), kšynk 'Keş'in, Keş'e

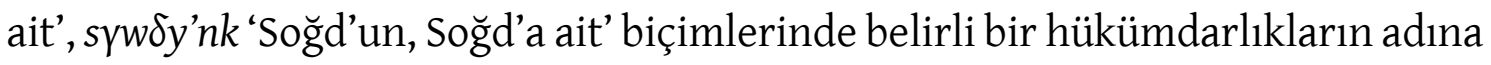
eklenmiş bir vaziyette karşımıza çıkar. Bununla beraber, bu eke Muğ Dağı Soğdça 


\section{$J(\Theta)$}

belgelerinde görülen şahıs adları muhtevasında denk gelinir: 1. Mahyan 'Ay kömeğine sahip'; 2. Apvahyan 'Su mabudu kömeğine dayanan'; 3. Parnyan 'Tali ve mutluluk mabudu (yardımına dayanan)'; 4. Krişnayan 'Güzellik mabudundan (kömek alan)' (Lurje 2010: 72, 117, 210, 235, 301) vs.

Ülke adı olarak Turan sözcüğünün çok eski tarihlerden itibaren Türklerle o veya bu derecede bağlantılı olduğu konusunda tartışmalar devam etmektedir. Bu kelimenin kadim Türklerle direk olarak ilişkili veya aksi olduğu meselesini daha sonraki çalışmalara bırakmakla beraber, ünlü İranist bilim adamlarının arasında da bu konuyu eleştiren araştırmacıların bulunduğunu belirtmeliyiz. Bilhassa, İranist FRYE, İranî toplulukların en eski kitabı Avesta'da görülen Tur veya Tura adını kadim Türklerle ilişkilendirerek, başlangıçta onun Doğu İranlılar için kullanılmakla birlikte çok eskiden beri Türk topluluklarını ifade ettiğini yazmıştır. Ona göre, Türk etnik adının kendisi de adı geçen Tur kökünden oluşmuş ve erken orta çağlara gelince artık 'Türkler' anlamında kullanılmaya başlamıştır (Frye-Say1lı 1946: 97-131).

Turan yer adının Türklere ne denli ilişkili olduğunu ve onun tam olarak hangi tarihlerde, orta çağlarda mı, yoksa daha eski dönemlerde mi belirdiğini, 'Türkler ülkesi' anlamında kesin olarak hangi tarihlerde genellik kazandığını kanıtlamak için biraz yukarıda değindiğimiz gibi Semerkant ve civar bölgeler sikkelerinin daha derin araştırılması gerekir. Özellikle, adı geçen sikkeler arasındaki 'Turan hükümdarı Kağan' unvanlısına müracaat edildiğine konu epey aydınlaşacak gibidir. Bu sikke çeşidinde bulunan hükümdarın fiziksel biçimi (sakalsız yuvarlak yüz, hafif çekik göz, omuzlara kadar uzayan saç) Çaç 'Taşkent' ve Fergana'da darp olunan Batı Köktürk dönemi sikkelerdeki tasvirlerle hemen hemen aynıdır (Babayarov 2007: 40-63) (bk. Levha II-III).

Konuya ilişkin genel algılama, yani Turan terimi, kadim dönemlerde, hatta erken orta çağlarda Doğu İranlılar (yani Soğd, Baktrî, Harezm ve s.) toplulukların yaşadığı topraklar için kullanılmıştır. Bu terimin Türk toplulukları ve onların yaşadığı bölgelere nispeten kullanılmaya başladığı tarih ise daha geç dönemlere denk gelir. Onun Türkistan ile eşanlam taşımaya başlaması da epey geç dönemlerle, özellikle Karahanlılar dönemiyle ilişkili olduğu konusuna dönersek, ilkin 


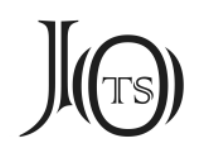

Turan coğrafî adı sabit bir biçimde 'Türklerin memleketi' anlamında kullanılmasına İranlı düşünür Firdevsînnin (940-1020) Şah-name eseri aracllık yapmış gibi gelmektedir. Nitekim FRYE, gerçekten de bölgede İslam dini yayıldıktan sonra Müslüman müellifleri Türkleri kadim Turanlılarla denkleştirmeye başladıkları, böylece Turan terimi 'Türkler diyarı' anlamında edebî ve tarihî eserlerde yer almaya başladığını yazmıştır (2002: 66). Ancak, sadece Firdevsî değil, diğer Müslüman yazarları da bu terimi güya çok eskiden varmış gibi algılamaları bu görüşün eksik yönlerinin bulunduğunu düşündürmektedir. Özellikle, Firdevsînin çağdaşı, yukarıda kısaca durduğumuz Ebu Reyhan Birunî (973-1048), Horasan'daki Mezduran (burası şimdiki Türkmenistan'ın güney-batı topraklarında yer alan Serahs sıradağlarında bulunan ahali meskeni) adını 'Merz-i Turan' olarak sunması ve bu adın sözcük anlamıyla 'Türklerin sınırı' olduğunu vurgulaması ayrıcalıklıdır: 'Mazduran, geçit, onu Merz-i Turan, yani Türkler sınırı olarak adlandırırlar' (Qanun-î Mas’udi, 570 [Beruniy 1973: 466]).

Herhalde Birunî̀nin bu açıklaması Firdevsî şah-name'sinin etkisiyle değil, belki de ta o dönemde adı geçen terimin 'Türkler ülkesi' anlamında geniş çapta yayılmış olmasından ileri gelmekteydi. Bu kavramı X. yüzyılın sonlarına doğru, bilhassa Karahanlıların Maveraünnehir'de kendi egemenliklerini sağladığı 992999 yılları arasına sığdırmak mantıklı gelmemektedir. Nitekim Birunî kendi eserlerini yazmaya başladığı tarihlerde, yani Karahanlılar bu bölgede kendi hâkimiyetini sabit bir biçimde düzenleyemediği bir sırada Turan'ın 'Türkler ülkesi' anlamını kazanıvermesi kabul edilemez. Hele bu dönemde Karahanlıların egemenliğinden epey uzakta olan Horasan'daki Medzuran'ın bu anlamı kazanmasını düşünmek imkânsızdır.

Bu olaylardan epey önce eserini yazan Ebu Abdullah el-Harezmî (öl. 997) kendisinin Mefatihü'l-Ulum 'Bilimler anahtarı' adlı eserinde Birunî’nin kaydettiği bilgiyi ondan önce ve biraz farklı bir biçimde şu şekilde sunması bu görüşümüzü desteklemektedir:

'Ceyhun nehrinin sahillerini İranlılar Merz-i Turan adlandırırlar, yani Türklerin sınırı anlamında, ancak; Horasan ahalisi onu Merz-i İran, yani Irak sınırı olarak adlandırırlar' (Баходиров 2009: 114). 


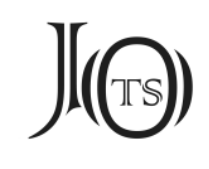

Burada Irak adının gerçek İran toprakları için kullanıldığı orta çağ kaynaklarından anlaşılmaktadır. Bu dönem Müslüman kaynaklarında Irak-ı Arap ve Irakı Acem gibi coğrafî terimler mevcut olup, onlardan ikincisi Arap dışı ülkeleri, özellikle İran ahalisini ifade ettiği bilinmektedir.

Harezmî ve Birunînin Turan hakkındaki bu bilgilerini destekleyen diğer bir bilgi de, onlardan biraz sonra XI. yüzyılın ikinci yarısında yaşayan Horasanlı şair Esedi Tusî tarafından düzenlenen Lugat-i Furs eserinde kaydedilmektedir: “Turan, doğuda bulunur, Türkistan ve Horasan'ın bir kısmının adıdır" (Bayevskiy 1980: 88).

Bu dönemde Turan terimi coğrafî bir terim değil, belki şahıs adı sıfatıyla da farklı kaynaklarda karşımıza çıkmaktadır. Nitekim miladi VII. yüzyılın ortalarına doğru Semerkant'a elçi gönderen komşu Çaganiyan hükümdarlı̆̆ının yöneticisinin adı Soğd yazısıyla twr'ntš ‘Turan-Taş’ biçiminde Afrasiyab (Semerkant) sarayı duvar resimlerinde betimlenen yazllarda görülmektedir (Al'baum 1975: 55). LIVŠıC, bu şahıs adını İranî temelde 'Turanlıların cengâver baltası' olarak açıklaması ilgi çekicidir (2006: 63-64). Dönemin, hem Çin ve Arapça kaynakları, hem de nümizmatik bilgiler burada Türk asıllı hanedanın hüküm sürdüğünü tespit etmektedir. 644 yılında bölgeden geçen Çinli seyyah Xuan-Zang, buranın yöneticisini Türk olarak zikreder (Shaban 1971: 485). Taberî de 710 yillarında Saganiyan'1 (Çaganiyan) eş-Şazz olarak kaydetmiş (1987: 124, 400) ki, araştırmacıların onun Türkçe Şad unvanlı yönetici olduğunu ileri sürmüşlerdir (Gibb 1930: 10). Buna benzer diğer bir kanıt, Firdevsînnin Şah-name'sinde Türk hakanlarından birinin kızı olarak Sasanî Şehinşah'ın hanımı sıfatıyla zikredilen kadının adı (aslında lakabı) olan Turanduht'ın sözcük anlamı 'Turan kızı', 'Turanlı kız’ ve 'Türk hükümdarının kızı' olmasıdır.

Turan sözcügü oldukça saf Türk ortamında da şahıs adı sıfatıyla sıkça görülür. Örneğin, İrtiş nehri havzasından (Altaylar) bulunan Eski Türkçe yazılı taş yazıtta Alp Turan adı görüldüğ̈u gibi, Çin yıllıklarında da Tu-jue (Köktürk) hükümdarlarından birini adı Ton-ga Du-lan Ko-han ‘Tonga Turan Kağan’ biçiminde geçer (Biçurni I, 1950: 239-242; Gömeç 1997: 29). Önemlisi, her iki bilgi de Köktürk kağanlığı dönemiyle bağlantılı olmasıdır. 


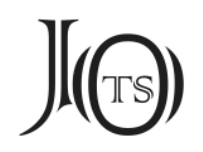

Turan sözcüğünün ‘Türk' etnik adı arasında belirli bir bağ bulunduğunu kanitlayan diğer bir delil, Doğu İranî bir dil olan İslam öncesi Harezm yazılarında ve Soğdça Mug Dağı belgelerinde şahıs adı sıfatıyla geçen twrk sözcüğüyle bağlantılıdır. Bilhassa, Humbuz-Tepe'de (Harezm bölgesi) bulunan seramik parçalarda kadim Harezm yazısında twrk tabiri görülmekte olup, bazı araştırmacılar onu 'Tur, Turanlı' anlamındaki Eski İranîce *Tūra-ka etnik adıyla bağlamaya eğilimlidirler (Livşits-Mambetullayev 1986: 39). Ancak, onlardan farklı olarak Soğd dili uzmanı LURJE, Soğdça belgelerde geçen twrk tabirini Türk etnik adıyla bağlamakta ve onun belirli bir şahısın etnik aidiyeti ile bağlantılı lakap olarak geçtiğini vurgulamaktadır (2010: 396). Bizce, LURJE tarafından bildirilen bu görüş gerçekleri yansıtmakta olup, bu değerlendirme kadim Harezm yazısındaki bilgiler için de geçerlidir. Zaten, Harezm ve Soğd bölgeleri yakın komşular olarak, diğer İranî dillere nazaran birbirlerine yakınlık arz etmekle beraber, bu dönemde her ikisi de aynı siyasî çatı altında - Köktürk Kağanlığı egemenliğindeki birer vaha hükümdarlıkları idi.

Bazı bilim adamları Turk/Türk etnik adının kökeni tur-/tür- olduğunu, onun Eski Türkçe çokluk eki $\{+k\}$ aracıllğıyla Turlar/Türler anlamı yüklenen Türk adı ortaya çıktığını varsaymaktadırlar. Büyük ihtimalle, belirli bir toplum adını ifade etmek için Eski Türkler Tur- $k$, İranlılar ise Tur-ān ( $\{+a \bar{n}\}$ İrani dillerde çokluk eki) tabirlerini kullanmış olup, bunun temelinde 'Türklerin yaşadığ bölge' anlaminda 'Turan' yer adı oluşmuştur (Fray 2002: 66-67; Kamoleddin 2006: 11).

Kısacası, VI. yüzyılın sonu ile VII. yüzyılın ilk yarısında darb olunan $x w \beta$ twrnyn 'Turan hükümdarı' veya $x w \beta$ twrnyn $x$ ' $\gamma^{\prime} n$ 'Turan hükümdarı Kağan' tabirlerinin bulunduğu Semerkant sikkelerinin, hem barındırdığı unvanlar, hem de yansıttığı hükümdar tasvirleri onların Köktürklere dolaylı veya dolaysız olarak bağlantılı olduğunu tasdik eder. Eğer daha erken orta çağlarda bile Turan ve Türkistan terimleri hemen hemen aynı anlamda kullanılmaya başladığından yola çık1lırsa, bu dönemde Turan sözcü̈̆ünün Köktürk Kağanlı̆̆ını ifade eden tabirlerden biri sıfatıyla kullanıldığı anlaşılır. Üstelik sikkelerde yer alan tabirlerin resmî anlam taşıdığını hesaba katarsak, Köktürk kağanlarının kendi devletini 'Turan' olarak da adlandırdıkları ihtimal dışı olmayacaktır. 


\section{$J(\Theta)$}

\section{Sonuç}

VII. yüzyılda Köktürk kağanları adına Semerkant’ta bastırılan Soğdça yazılı bakır sikkelerde 'Turan Kağan'ı' tabirinin geçmesi, şu yüzyıla ait Soğdça ve Ermenice yazılı eserlerde 'Türkistan' tabirinin görülmesi bu iki coğrafî adın en azından Köktürk Kağanlığı döneminde eşanlamlı olduklarının delilidir. Gerçi, Köktürkler yönettiği toprakları bütünleyici bir ad olarak kendi dilleri kurallarına göre Türk Eli, Türk Kağanlığı demişseler de, sonradan komşuları veya kendi tebaaları olan gayri Türk toplumlar etkisinde Turan ve Türkistan tabirini de kullandıkları anlaşılmaktadır.

Her iki coğrafî ad üzerine buraya kadar kısaca eleştirdiğimiz bu bilgiler, Turan ve Türkistan gibi eşanlamlı bu terimlerin Karahanlılar zamanında da kesintisiz bir biçimde kullanılmaya devam ettiğini düşündürmektedir. Karahanlı döneminde bu coğrafî adların paralel olarak kullanıldığının daha net örneği yukarıda Balasagunlu Yusuf'un sözleri örneğinde sunulmuştu. Nitekim Karahanlı tarihi uzmanı HUNKAN'ın o dönemlerin Arap ve Fars kaynaklarından topladığı şu gibi bilgiler de bu kayıtları doğrulamaktadır: 'Bazen de hanedan mensuplarının hâkim olduğu coğrafyaya nispetle ülke adı olarak, 'Hanan-1 Türkistan' ya da 'Hanat-1 Türkistan' (Beyhakî 1977: 87, 103, 944), 'Memleket-i Türk' (Şebankareî 1376: 59), 'Zemin-i Turan' (Cüzcanî 1363: 230) ve 'Memalik-i Türkistan' (Cüzcanî 1363: 254), ülkenin yöneticisi ise 'Han-1 Türkistan' (Beyhakî 1977: 667; Nizamü'l-Mülk 1982: 148,163) ve 'Hakan-1 Türkistan' (Cüzcanî 1363: 230), ayrıca 'Türk Hakan'1' (íbnü'l-Adim 1976: 33), 'Havakinü’t-Türk' (Türk Hakanları) (Karşî 1898: 130) ve 'Hanan-1 Türk (Türk hanları)' şeklinde kaydedildiklerine rastlamak da mümkündür' (Hunkan 2005: 9; Hunkan 2007: 79-80).

Eğer adı geçen kaynaklardaki bu coğrafî tabirlerin aynı vakitte, aynı hükümdarlığı ve ülkeyi ifade ettiğine bakılırsa, bu geleneğin kökü daha erken dönemlere dayandığı ve bu tabirleri kullanırken, yazarların onların eşanlamlı olduğunun farkında oldukları anlaşılmaktadır. Hatta daha sonraki dönemlerde bile bu geleneğin devam etmesi de bu görüşü destekler. Özellikle, Babürlüler döneminde Timur'un 'Turan meliki, Türkistan emiri' sıfatıyla kaydedilmesi, Timur'un kendisi ise Uluğ-tağ (Ulutau/Merkezi Kazakistan) bitiğini ‘Turan'ın sultanı’ olarak yazdırması bunun en net örneğidir (Sertkaya 2007: 36-37; Sodıkov 2016: 143). 


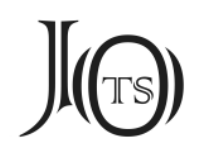

Kısacası, Türkistan terimi uzun asırlardan beri Orta Asya'nın büyük bir kısmı için, daha doğrusu Hazar Denizi'nin doğusundan Altay Dağları'na kadar, Kuzey Afganistan'dan Ural Dağları'na kadar uzanan geniş toprakların coğrafî adı sıfatıyla kullanıla gelmiştir. Gerçi, bu terim bazen genişleyip, bu topraklardan daha büyük hudutları kapsamış, bazen ise daralarak, nispeten küçük hudutları içermiştir. Ancak, Türkistan, esas olarak adı geçen topraklar için genel ve ortak ad görevini yaptığından dolayı biri diğerinden farklı dillerdeki kaynaklara konu olmuştur. Yani erken orta çağlarda bu ad daha genişleyerek Kuzey Kafkasya (Dağıstan) ve Azerbaycan'ı da kapsamış ve İdil (Volga) nehrinden doğudaki Türk ülkelerine nispeten kullanılmıştır. Bir müddet, orta çağların belirgin bir vakit diliminde daralarak, Sırderya nehrinin orta havzası ve onun doğusundaki Yedisu bölgesini ifade etmiş olmasına rağmen, genel olarak bu terim doğuda Altaylar, batıda Hazar, kuzeyde Urallar ve güneyde Kuzey Afganistan arasında yer alan geniş topraklar için kullanıla gelmiştir.

\section{Kaynakça}

AHMEDOV, A. (1992). “Nega Turon Dep Ataladi?”, Turon, 1: 5-6.

AL’BAUM, L. N. (1975). Civopis' Afrasiaba, Taşkent.

ARAT, R. R. (1947). Kutadgu Bilig I: Metin, İstanbul: Millı̂ Eğitim Basımevi.

ARAT, R. R. (1959). Yusuf Has Hâcib, Kutadgu Bilig II: Tercüme, Ankara: Türk Tarih Kurumu Yayınları.

ASKAROV, A. (1997). Nekotoriye Voprosı İstorii Stanovleniya Uzbekskoy Gosudarstvennosti, 3/4: 65-76.

BABAYAR G. (2017). “Kağan Unvanlı İslam Öncesi Semerkant Sikkelerinin Yeni Çeşitleri, Old Turkic Values-2017", Information Package of the International Research and Practical Conference (May 18 - 19, 2017), Astana: 38-51.

BABAYAR, G. (2007). Drevnetyurkskiye monetı çaçskogo oazisa (VI-VIII vv.), Taşkent.: Izdetal'stvo Natsional'noy Biblioteki Uzbekistana İmeni Alişera Navoy.

BABAYAR, G. (2007). Köktürk Kağanlığı Sikkeleri Kataloğu, Ankara: TIKA Yayınları. 


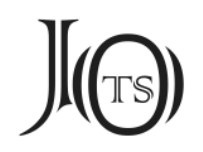

BABAYAROV, G.; A. KUBATIN (2010). “K Novomi Çteniyu i İnterpretatsii Legend na Nekotorıx Doislamsikix Monetax Samarkandskogo Sogda”, Tarix Tafakkuri "Barkamol Ablod" Yiliga Bagışlangan Respublika Tarixçi Olimlarining İlmiy İşlar Tüplamı, Mas'ul Muxarrir va Tuzuvçı: Ş. H. VOHIDOV, Buhara: 22-32.

Babur Zaxiriddin Muhammed (1958). Baburname, Per. M. SAL'YE, Taşkent.

BAXODİROV, R. (2009). İstoriya Vostoka v “Klyuçak Nauk”, Şarkşunoslık, 14: 108117.

BAYEVSKIY, S. İ. (1980). Geografiçeskiye Nazvaniya v Rannix Persidskix Tolkovıx Slovaryax (XI-XV vv.), Moskva.

Beruniy Abu Rayhan (1973). Kanon Ma’suda, İzbrannıye Proizvedeniya, V. Çast Pervaya, Peredov i Primeçaniya B. A. ROZENFEL’DA; A. AHMEDOVA, Taşkent.

Bİ, B.; SIMS-WILLIAMS, N. (2015). "Sogdian Documents from Khotan, II: Letters and Miscellaneous Fragments", Journal of the American Oriental Society, 135/2: 261282.

BİçURIN, N. Y. (1950-1953) Sobraniye Svedeniy o Narodah, Obitavşih v Sredney Azii v Drevniye Vremena, I-III, Moskova-Leningrad: Izd. AN SSSR.

BOBOYAROV, G. (2004). İlk Urta Asr Manbalarida “Turkiston” Atamasi, “Üzbek Xalkining Kelib Çikişi, İlmiy-Metodologik Yandaşuvlar, Etnogenetik va Etnik Tarix" Mavzusidagi Respublika İlmiy-Nazariy Seminar Materiaallari, Taşkent: 40-43.

BURIYEV, O. (1997). Temuriylar Davri Yazma Manbalarida Markaziy Osiya, Toşkent.

DAMES, M. L. (1986). “Afghānistān”, Encyclopedia of Islam, Brill, 1: 221a-223b.

FRAY, R. (2002). Naslediye İrana, Moskva.

FRYE, R. N.; A. SAYILI (1946). “Selçuklulardan Evvel Orta Şark’ta Türkler”, Türk Tarih Kurumu Belleten, 37: 133-167.

GIBB, H. A. R. (1930). Orta Asya'da Arap Fütuhatı, Çev. M. HAKKI, İstanbul: Evkaf Matbaas1.

GÖMEÇ, S. (1997). Kök Türk Tarihi, Ankara: Türksoy.

GYSELEN, R. (2002). Nouveaux matériaux pour la géographie historique de l'empire sassanide: sceaux administratifs de la collection Ahmad Saeedi, Paris: Peeters Publishers. 


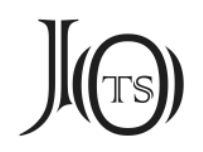

HUNKAN, Ö. S. (2005). “Orta Asya'da X-XIII. Yüzyıllarda ‘Türk’ Adı Üzerine Bazı Kayıtlar”, Hacettepe Üniversitesi Türkiyat Araştırmaları Dergisi, 2: 5-12.

HUNKAN, Ö. S. (2007). Türk Hakanlı̆̆ı (Karahanlılar), 2. Baskı, İstanbul: IQ Kültür Sanat Yayınları.

KAMOLIDDIN, Ş. (2002). “K Voprosu ob Upotreblenin Geografiçeskix Nazvaniy Maverannaxr i Turkestan”, Özbekistan Tarixi, 4: 61-68.

KAMOLIDDİN, Ş. (2006). Drevnetyurkskaya Toponimiya v Sredney Azii, Taşkent.

LIVŠIC, V. (2006). “The Sogdian Wall Inscriptions on the Site of Afrasiab”, Rivista degli studi orientali, Nuova Serie, 78, Supplemento No. 1: 59-74.

LIVŞİTS, V. A. (1981). “Sogdiyskiy Yazık”, Osnovı İranskogo Yazıkoznaniya, Sredneiranskie Yazıki, Moskva.

LIVŞi̇TS, V. A. (2008). Sogsiyskaya Epigrafika Sredney Azii i Semireç'ya, St. Petersburg.

LIVŞíTS, V. A.; M. M. MAMBETULLAYEV (1986). Ostrak iz Xumbuz-Tepe, Pamyatniki İstorii i Literaturı Vostoka, Moskva.

LURJE, P. (2010). Personal Names in Sogdian Texts, Iranisches Personennamenbuch, Band II: Mitteliranische Namen, Faszikel 8, Wien: Verlag der Österreichischen Akademie der Wissenschaften.

MAHMUDOV Q. (2003). Qadimgi Turkiston Tarixi, Taşkent.

MANNONOV, B. (1998). Turkiston va Markaziy Oziye, Mulokot, 2: 6-8.

MARKWART, J. (1938). Wehrot und Arang, Untersuchungen zur mythischen und geschichtlichen Landeskunde von Ostiran, Leiden: Brill.

Pahlavi Texts. (1987). The Bundahis-Bahman Yast, and Shayast La-Shayast, Translated by E. W. WEST, 5/1, Delhi: Clarendon Press.

SERTKAYA, O.F. (2007). “Timur Bek'in Tohtamış Han'a 793=1391'de Yapmış Olduğu Seferinin Arap ve Uygur Harfli Kitabeleri (Karsakbay Yazıtı)”, Ölümünün 600. Y1lında Emir Timur ve Mirası Uluslararası Sempozyumu (26-27 May1s, 2005), Ed. A. KARA; Ö. İşBİLİR, Doğu Kütüphanesi, İstanbul: 36-37.

SHABAN M.A. (1971). "Khurasan at the Time of Arab Conguest", Iran and Islam: Memory of the Late Vladimir MINORSKY, Edinburg: 480-490. 


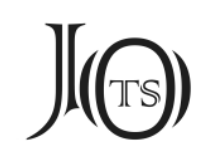

SIMS-WILLIAMS, N. (1989). “Sogdian”, Compendium Linguarum Iranicarum, Ed. R. SCHMITT, Ludwig Reichert, Wiesbaden: 173-192.

SMIRNOVA, O. I. (1981). Svodniy Katalog Sogdiyskih Monet: Bronza, Moskva: Izdatel'stvo "Nauka" Glavnaya Redaktsiya Vostoçnoy Literaturı.

SODİKOV, K. (2016). İlk va Urta Asrlarda Yaratılgan Turkiy Xuccatlar, Taşkent.

TABARI (1987). İstoriya at-tabari, İzbranniye otrıvki, Per. s arab. V. İ. VELYEVA et al, Taşkent: FAN.

TAŞAĞIL, A. (1999). Gök-Türkler II, Ankara: Türk Tarih Kurumu Yayınları.

TER-MKRTIÇYAN, L. X. (1979). Armyanskiye İstoçniki o Sredney Azii V-VII vv., Moskva.

URINBOYEV, A. (1960). Abdurazzok Samarkandiyning Hindiston Safarnomasi, Toşkent. 


\section{J(ㅇ)}
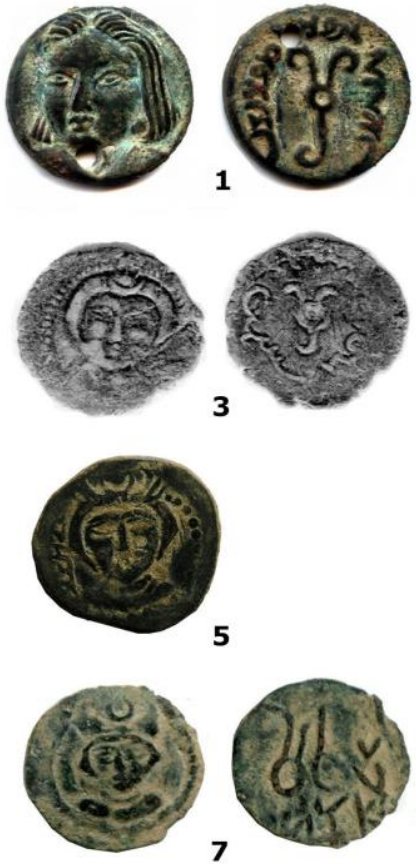
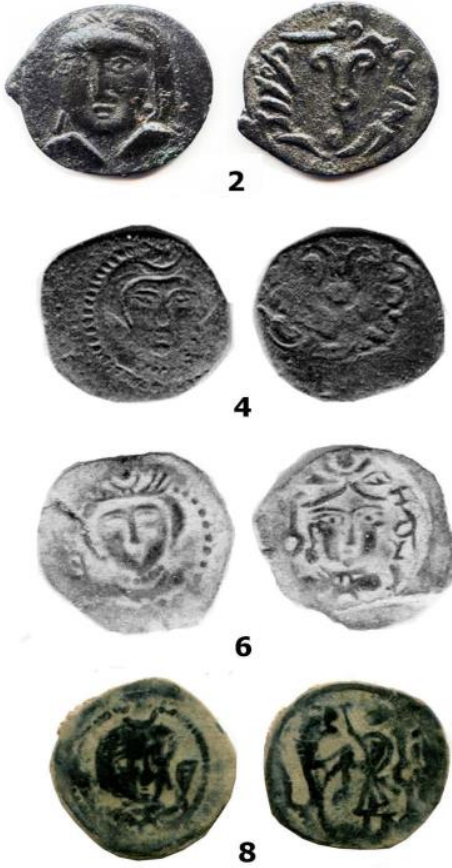

Levha I. "Kağan" unvanlı İslam öncesi Semerkant sikkeleri
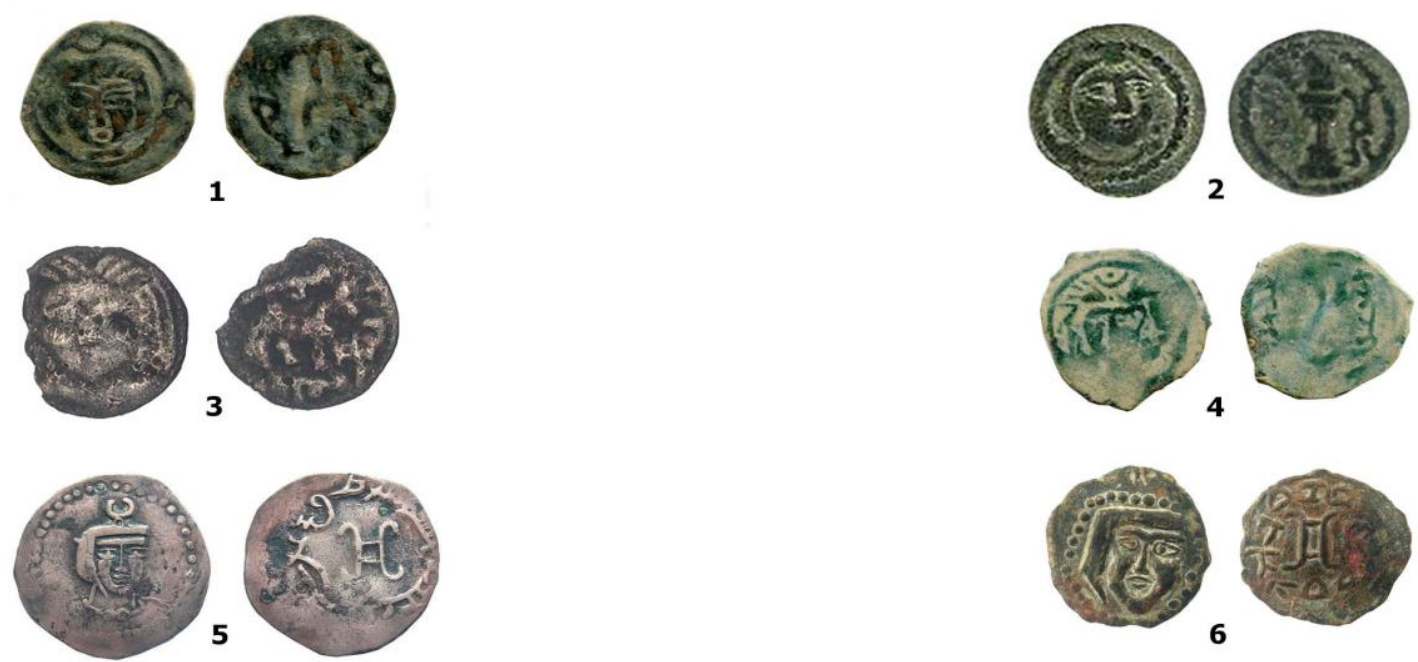

Levha II. İslam öncesi Orta Asya sikkelerinden örnekler

(Soğd? - 1, Buhara - 2, Nahșep - 3, Ustuşana - 4, Çaç - 5-6) 


\section{J(৫)}
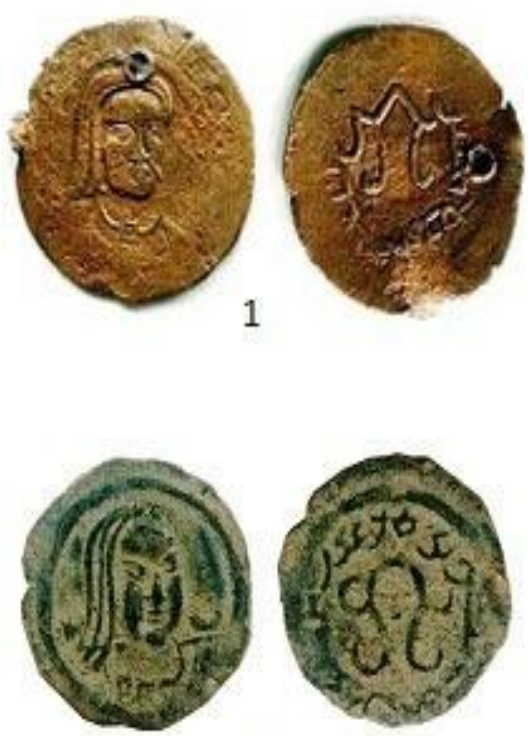

3

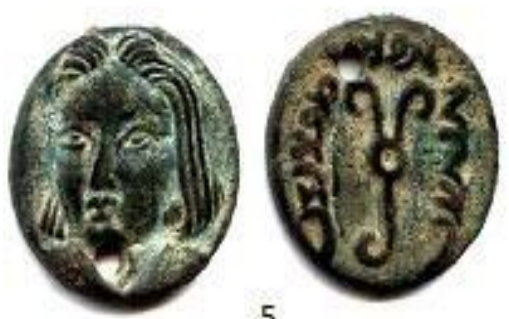

5
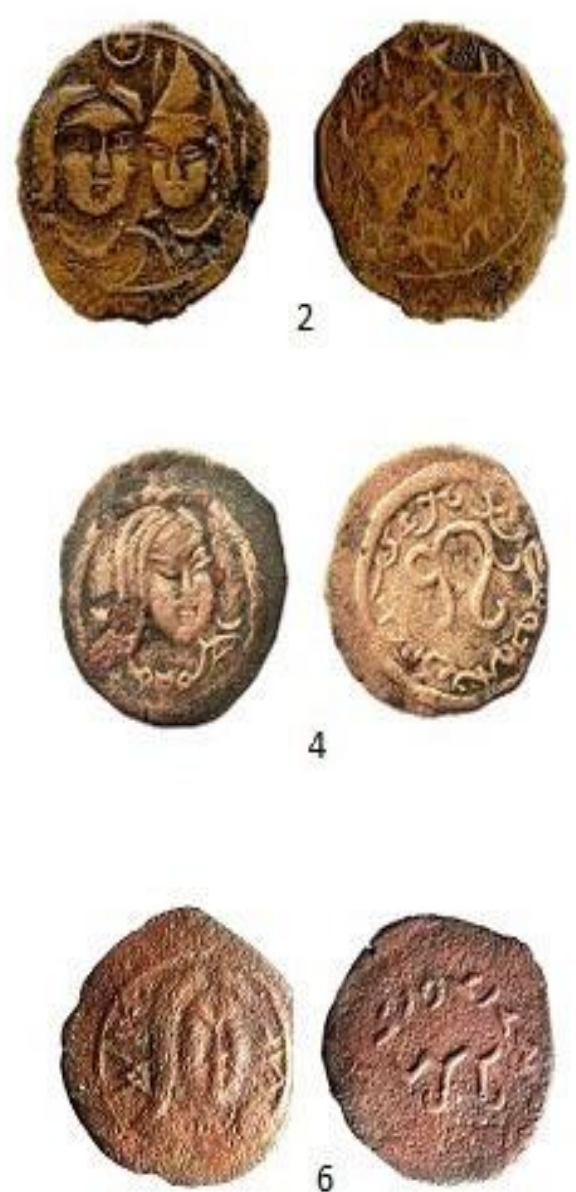

Lerha III. Çaç'ta darb olunan bazı Batı Köktürk Kağanliğı sikkeleri (1-2); Çaç Teginleri (3-4); Semerkant' in "Kağan" unvanlı siłkkesi (5), Fergana Așina hanedanının sıkkesi (6) 


\section{J(৫)}

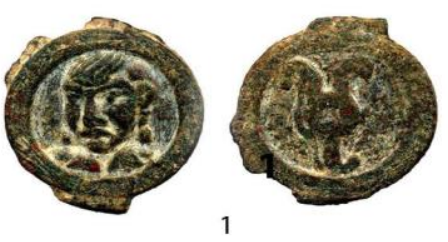

Grup I. 1. tip
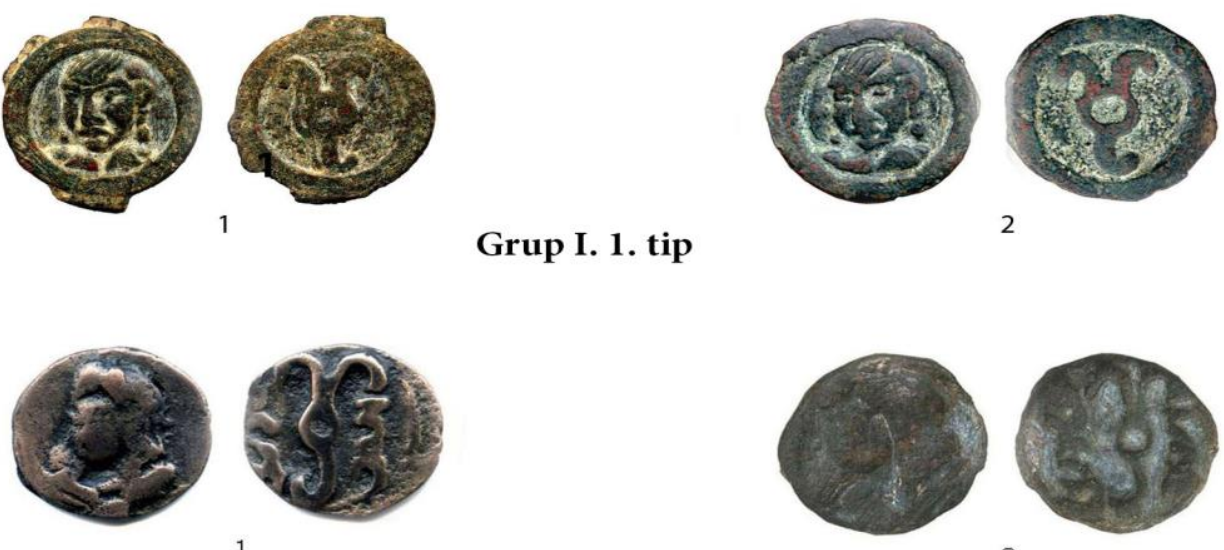

1

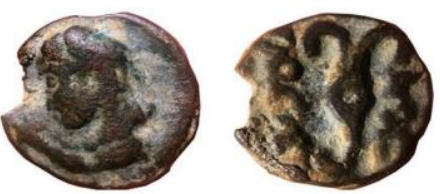

4

Grup I. 2. tip
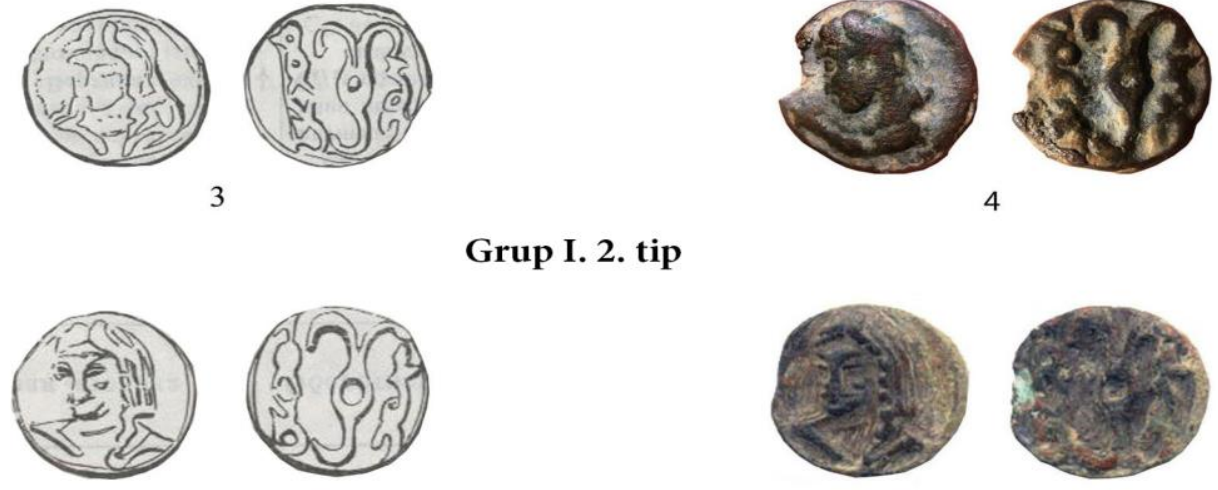

3

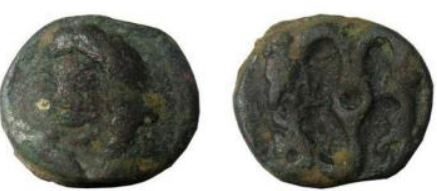

3

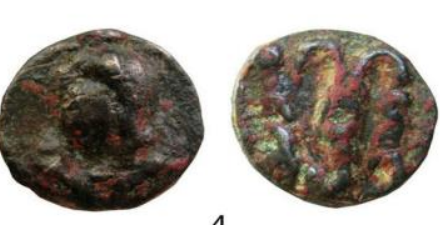

Grup I. 3. tip
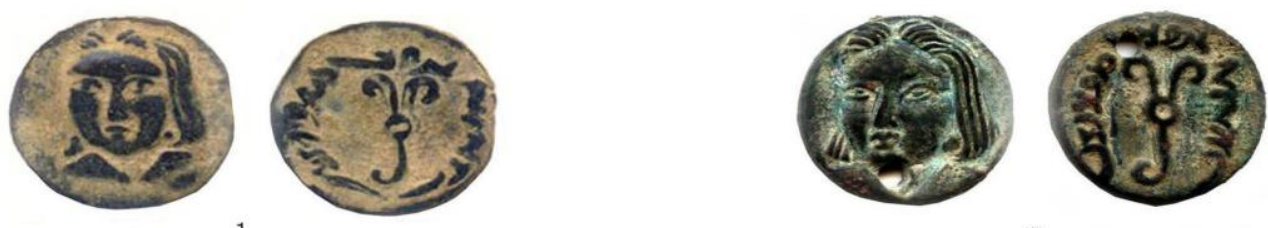

2

Grup I. 4. tip

Levha IV. Semerkant bölgesinin İslam öncesi Eski Türk sikkeleri (Grup I) 


\section{I(O)}

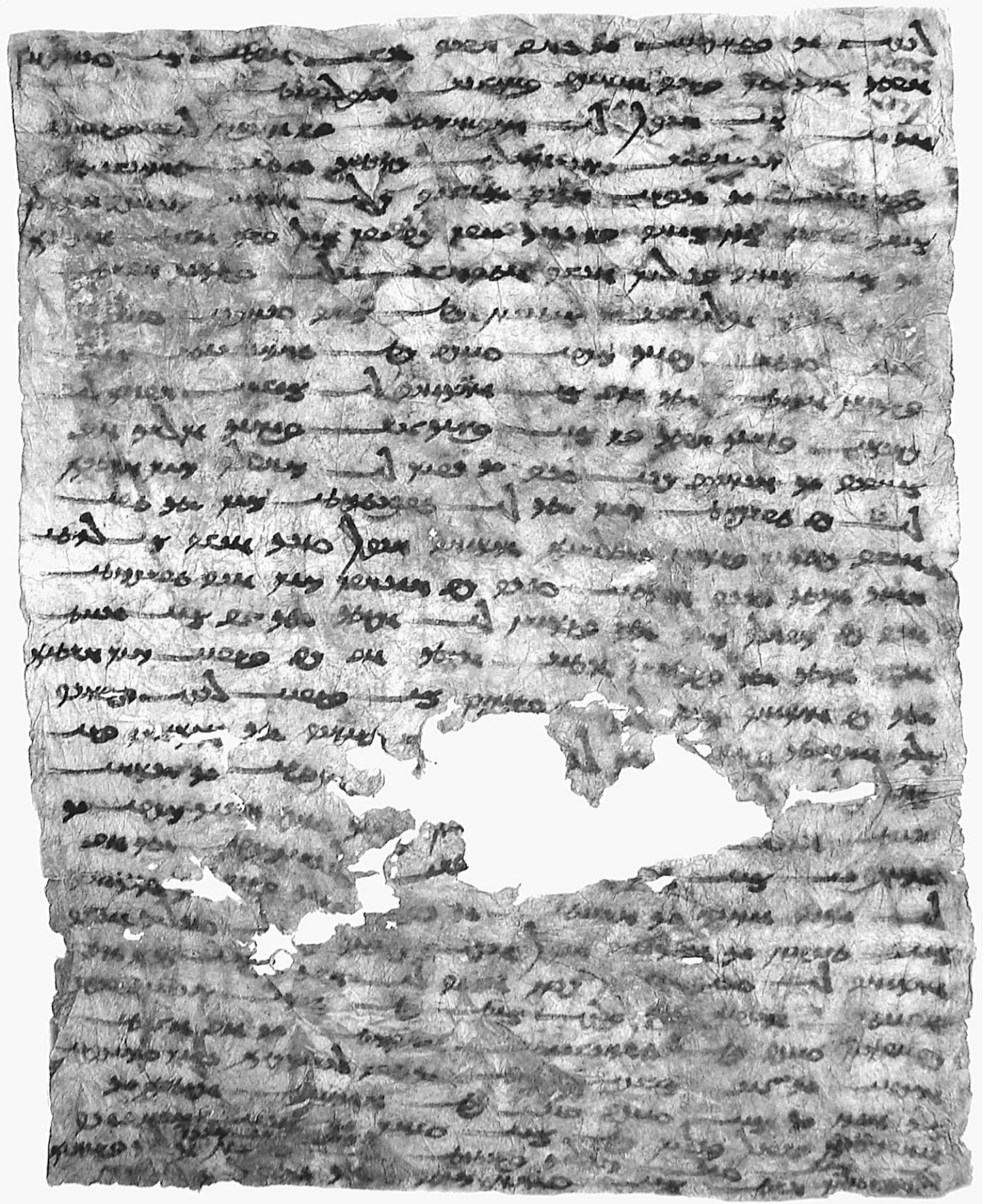

Levha V. 'Türkistan' teriminin geçtiği Hotan (Doğu Türkistan)'da bulunan 8. yüzyıla ait Soğdça belge (Bi-Sims-Williams 2015: 263) 